\title{
Slag melting temperature and contact angle on high carbon containing refractory substrates
}

\section{(Temperatura de fusão e ângulo de contato de escórias em substratos de concretos refratários contendo alto teor de carbono)}

\author{
A. P. Luz $^{1}$, S. Ribeiro ${ }^{2}$, V. G. Domiciano ${ }^{3}$, M. A. M. Brito ${ }^{3}$ V. C. Pandolfelli ${ }^{1}$ \\ ${ }^{1}$ Materials Engineering Department, Federal University of S. Carlos, S. Carlos, SP 13565-905 \\ ${ }^{2}$ Materials Engineering Department, School of Engineering of Lorena - EEL-USP, Lorena, SP 12600-970 \\ ${ }^{3}$ Magnesita S.A., Research Center, Contagem, MG 32210-902 \\ ana_light@uol.com.br,vicpando@power.ufscar.br
}

\begin{abstract}
In this work the sessile drop technique was used in order to evaluate the melting temperature of synthetic and industrial slags, and their contact angle as a function of time and temperature on substrates of an $\mathrm{Al}_{2} \mathrm{O}_{3}-\mathrm{SiO}_{2}-\mathrm{SiC}-\mathrm{C}$ castable containing 10 wt.\% of carbon or its matrix. The best experimental conditions for the evaluation of the wetting behavior of refractory castables were attained when $25 \times 25 \times 10 \mathrm{~mm}^{3}$ matrix substrates and cylindrical slag pellets of $3 \mathrm{~mm}$ diameter and $5 \mathrm{~mm}$ high were used. This substrate - slag set resulted in contact angle values with good reliability. Small differences between the contact angle behavior on ground and polished matrix surfaces for synthetic slags were also detected. Additionally, industrial slags containing various oxide components, showed high values of contact angles and lower liquid spreading when compared with synthetic slags. This difference can be associated to the interaction liquid-solid at the material interface. Besides that, the wetting experiments were presented as a good alternative for measuring the melting temperatures of slags, as their values are difficult to determine due to the high oxide variety in the industrial slag compositions and the interaction between the slag and the substrate.
\end{abstract}

Keywords: wettability, carbon containing refractory, contact angle, melting temperature.

\section{Resumo}

Neste trabalho a técnica da gota séssil foi usada na avaliação da temperatura de fusão de escórias sintéticas e industriais e de seus ângulos de contato, em função do tempo e da temperatura, sobre substratos de um concreto $\mathrm{Al}_{2} \mathrm{O}_{3}-\mathrm{SiO}_{2}$-SiC-C que contém $10 \%$ - $\mathrm{p}$ de carbono ou sobre somente sua matriz. As melhores condições experimentais para a avaliação do comportamento de molhamento dos concretos refratários foram obtidas quando utilizados substratos da matriz de $25 \times 25 \times 10 \mathrm{~mm}^{3}$ e cilindros das escórias com 3 $\mathrm{mm}$ de diâmetro e $5 \mathrm{~mm}$ de altura. O uso deste conjunto substrato-escória proporcionou a obtenção de valores de ângulo de contato com boa reprodutibilidade. Pequenas diferenças entre o comportamento do ângulo de contato de escórias sintéticas sobre amostras da matriz com superfície retificada ou polida também foram verificadas. Adicionalmente, as escórias industriais que continham diversos óxidos em suas composições mostraram maiores valores de ângulo de contato e menor espalhamento dos líquidos quando comparados com as escórias sintéticas. Esta diferença pode estar associada à interação entre o líquido-sólido na interface destes materiais. Além disso, os experimentos de molhabilidade foram apresentados como uma boa alternativa para medir a temperatura de fusão de escórias, uma vez que estes dados são difíceis de serem determinados devido à grande variedade de óxidos presentes nas composições das escórias industriais e a possível interação entre escória e substrato.

Palavras-chaves: molhabilidade, refratários contendo carbono, ângulo de contato, temperatura de fusão.

\section{INTRODUCTION}

The wetting behavior as a function of time and temperature constitutes one of the most important aspects of high-temperature liquid-phase materials processing and it is a major tool for the modern metallurgy and foundry industry [1-4]. The wetting extent indicates how a liquid phase wets a solid surface and it is generally quantified in terms of the contact angle $(\theta)$ at the three-phase interface [5]. A contact angle of less than $90^{\circ}$ will correspond to a wetting liquid, whereas a greater value will indicate a non-wetting one.
Techniques to characterize the wettability are diverse [1$3,5-7]$, but the most commonly used is the sessile drop, which is simple to perform and allows quantitative wetting measurement for both, chemically inert and reactive systems. The contact angle can be calculated by the Young relationship (Eq. A), which is valid for an ideal surface (e.g., flat, perfect smooth, chemically homogeneous, insoluble, etc.) [8],

$$
\gamma^{\mathrm{LV}} \cos \theta=\gamma^{\mathrm{SV}}-\gamma^{\mathrm{SL}}
$$

where $\gamma^{\mathrm{LV}}, \gamma^{\mathrm{SV}}$ and $\gamma^{\mathrm{SL}}$ are the interfacial surface tensions 
of the liquid-vapor, solid-vapor and solid-liquid interfaces, respectively.

Real solid surfaces never satisfy all the conditions for the Young equation, due to the chemical heterogeneity and roughness. The contact angle value strongly depends on the solid surface quality and this can explain the differences among the results reported in the literature even for the same surface and wetting liquid $[4,6,7]$.

Only few papers involving the slag - refractory wettability are found in the literature [1,9-11]. Nevertheless, refractory wetting and corrosion by molten slags in the metallurgical processes is a key issue because the corrosion always speeds up the refractory wearing and it must be considered in the composition design for specific industrial vessels or equipment. As an example, castables for blast furnace main runners $\left(\mathrm{Al}_{2} \mathrm{O}_{3}-\mathrm{SiO}_{2}-\mathrm{SiC}-\mathrm{C}\right)$ often contain carbon in order to inhibit wetting and reduce slag penetration. The non-wetting behavior of carbon sources by oxide slags is also regarded as one of the advantages of using carbon bricks in the blastfurnace.

The slag-graphite wettability, kinetics and mechanism of molten $\mathrm{FeO}$ reduction reaction using the sessile drop tests were evaluated $[9,10]$. In these studies, a higher initial $\mathrm{FeO}$ content in the slag and high temperature led to a better wettability of graphite due to the chemical reaction between the slag and the solid surface. The interaction between a silicate slag (iron containing olivine slag) and a high alumina refractory using the sessile drop technique was evaluated [1]. Three different kinetic wetting stages were detected when using the sessile drop technique: wetting initiation, spreading, and, penetration and reaction. The wetting behavior in $\mathrm{MgO}$ samples with a rough surface, in contact with a silicate slag-based on fayalite was evaluated [11]. For this purpose, the authors used a special heating microscope and evaluated the horizontal and the rolling angle. According to them, by increasing the roughness of the $\mathrm{MgO}$ refractory surface, the contact angle decreased in close agreement with the Wenzel equation:

$$
\cos \theta_{a p p}=\operatorname{rcos} \theta_{Y}
$$

where $r$ is the average roughness ratio $(r=1$ for a smooth surface and $\mathrm{r}>1$ for a rough one), $\theta_{a p p}$ is the apparent contact angle (value attained experimentally when liquid is in contact with real solid surfaces) and $\theta_{Y}$ is the Young's contact angle. The rate of wetting is influenced by a number of parameters such as the substrate surface (e.g., roughness, microcavities, cracking, coatings, adsorbed layers, previous thermal or ionic cleaning, etc.), chemical heterogeneous surfaces, gaseous environment, interaction of the liquid with the substrate, temperature and intrinsic properties of the liquid medium [5].

According to Lee and Zhang [4], wetting must necessarily precede the penetration of the refractory by a molten slag or metal. The refractory corrosion process can be described as wetting, followed by penetration in the refractory porosity, chemical reaction and disruption of the refractory bonds and finally the washing, or erosion of the refractory by the revolving liquid. Wetting behavior gives an indication of penetration but not attack or corrosion.

In order to understand the slag - refractory corrosion process, it is firstly necessary to identify the mechanisms by which a slag wets the refractory when they first come into contact $[1,2,12]$. Thus, this experimental study is focused on the slag - refractory wetting process. The sessile drop technique was used in order to attain the melting temperature of the industrial and synthetic slags, and the contact angle behavior, as a function of time and temperature on an $\mathrm{Al}_{2} \mathrm{O}_{3}-\mathrm{SiO}_{2}-\mathrm{SiC}-\mathrm{C}$ castable or its matrix. This information is important when evaluating and understanding the thermodynamic aspects of the slag - refractory interaction. Besides that, there is still a need of a systematic evaluation and a better analysis of the interaction between slag and carbon containing refractory castable. In this work, some parameters such as: chemical composition and surface roughness of the substrate, the drop size effect and the effect of different slag compositions (industrial or synthetic), were evaluated using the wetting tests. The results attained can be also useful to better design this castable or matrix and provide further understanding of the chemical attack and corrosion process of these refractories, when associated with other evaluation techniques.

\section{MATERIALS}

In this work, an $\mathrm{Al}_{2} \mathrm{O}_{3}-\mathrm{SiC}-\mathrm{SiO}_{2}-\mathrm{C}$ castable composition containing $10 \mathrm{wt} . \%$ of carbon and ultralow cement content (Table I) was designed for the tests. The particle-size distribution was adjusted to a theoretical curve based on the Andreasen packing model with a distribution coefficient, $\mathrm{q}$ $=0.21$. Sodium polymetacrylate $(0.2 \mathrm{wt} . \%$, Darvan $7 \mathrm{~S}$, R.T. Vanderbilt, Norwalk, Conn.) was used as a dispersant for the castable matrix components and a non-ionic surfactant (HLB

Table I - 10SBC refractory composition (particle size $<4.75 \mathrm{~mm})$.

[Tabela I - Composição do refratário 10SBC (tamanho de partículas $<4,75 \mathrm{~mm}$ ).]

\begin{tabular}{lc}
\hline & $\begin{array}{c}\text { 10SBC } \\
\text { castable } \\
\text { (wt.\%) }\end{array}$ \\
\hline Brown fused alumina (4/10-200 mesh) & 44.0 \\
SiC (EC6R, 6/10-200 mesh) & 20.0 \\
Calcined alumina (A17NE) & 16.0 \\
Cement (Secar71) & 2.0 \\
Silica fume (971-U)@ & 1.0 \\
Carbon sources (pitch, coke, black fume) & 10.0 \\
Silicon powder@ & \\
Sodium borosilicate & 7.0 \\
Boron carbide & \\
\hline
\end{tabular}

Elfusa, Brazil. ${ }^{\natural}$ Treibacher, Brazil. "Almatis, EUA. aElkem Refractories,

Norway. Ferro Enamel, Brazil. ${ }^{\star}$ China Brasilis, China.

Unimetal and Nacional de Grafite, Brazil 
Table II - 10SBC matrix composition (particle size $<75 \mu \mathrm{m}$ ). [Tabela II - Composição da matriz da composição 10SBC (tamanho de partículas $<75 \mu \mathrm{m}$ ).]

\begin{tabular}{|c|c|c|}
\hline \multicolumn{3}{|c|}{10 SBC (wt \%) } \\
\hline Materials & $\begin{array}{l}\text { Castable } \\
\text { (fine } \\
\text { fraction) }\end{array}$ & $\begin{array}{c}\text { Matrix } \\
(<75 \mu \mathrm{m})\end{array}$ \\
\hline Brown fused alumina (200 mesh) & 5.0 & 10.5 \\
\hline $\mathrm{SiC}(\mathrm{EC} 6 \mathrm{R}, 200 \mathrm{mesh})^{\S}$ & 6.8 & 14.2 \\
\hline Calcined alumina (A17NE) & 16.0 & 33.5 \\
\hline Cement (Secar71) & 2.0 & 4.0 \\
\hline Silica fume (971-U) $\propto$ & 1.0 & 2.1 \\
\hline $\begin{array}{l}\text { Carbon sources } \\
\text { (pitch, coke, black fume)i } \\
\text { Silicon powdero }\end{array}$ & 10.0 & 21.0 \\
\hline Sodium borosilicate & 7.0 & 14.7 \\
\hline Boron carbide ${ }^{f}$ & & \\
\hline
\end{tabular}

Elfusa, Brazil. 'Treibacher, Brazil. "Almatis, EUA. oElkem Refractories, Norway. Ferro Enamel, Brazil. ${ }^{E}$ China Brasilis, China. 'Unimetal and Nacional de Grafite, Brazil.

$=8,4.0 \mathrm{mg} / \mathrm{m}^{2}$ ) was used as a wetting agent for the carbon sources [13]. Besides the castable, some matrix samples (Table II) were prepared in order to evaluate the wetting behavior of this substrate. It is known that matrix samples are more prone to react with liquid slags at high temperatures due to their high porosity and direct dissociation in the slag, owing to its finer grain size. The same dispersant and surfactant used in the castable preparation were also employed for the matrix composition. The water, dispersant and surfactant content was adjusted to provide enough fluidity.

Synthetic slags were prepared by mixing lime $(\mathrm{CaO})$, silica $\left(\mathrm{SiO}_{2}\right)$, alumina $\left(\mathrm{Al}_{2} \mathrm{O}_{3}\right)$ and magnesia $(\mathrm{MgO})$. The slag compositions are shown in Table III. In order to better evaluate the effect of $\mathrm{MgO}$ addition in the synthetic slags, it was chosen to keep constant the alumina content and the $\mathrm{SiO}_{2} / \mathrm{CaO}$ ratio for these compositions. To ensure its homogeneity, the mixture was sintered at $1400{ }^{\circ} \mathrm{C}$ for $3 \mathrm{~h}$. The sintered samples were crushed and milled in a WC shatter box. Each synthetic slag was analyzed by X-ray diffraction to identify their crystalline phases (Fig. 1). Industrial runner's slags were obtained from 5 different steelworks: Belgo (Brazil), Açominas (Brazil), Usiminas (Brazil), CST (Brazil) and Siderar (Argentina). The chemical composition of the

Table III - Chemical composition of the synthetic slags. [Tabela III - Composição química das escórias sintéticas.]

\begin{tabular}{ccccc}
\hline \multicolumn{5}{c}{ Synthetic Slags } \\
\hline$(\mathrm{wt} \%)$ & ES0 & ES5 & ES10 & ES15 \\
$\mathrm{CaO}$ & 48.09 & 45.33 & 42.57 & 39.82 \\
$\mathrm{SiO}_{2}$ & 38.91 & 36.67 & 34.43 & 32.18 \\
$\mathrm{Al}_{2} \mathrm{O}_{3}$ & 13.00 & 13.00 & 13.00 & 13.00 \\
$\mathrm{MgO}$ & 0.00 & 5.00 & 10.00 & 15.00 \\
\hline
\end{tabular}

Table IV - Chemical composition of the industrial slags. [Tabela IV - Composição química das escórias industriais.]

Industrial Slags

\begin{tabular}{cccccc}
\hline$(\mathrm{wt} \%)$ & Belgo & Açominas & Usiminas & CST & Siderar \\
$\mathrm{SiO}_{2}$ & 35.59 & 33.65 & 34.19 & 34.35 & 34.41 \\
$\mathrm{TiO}_{2}$ & 0.58 & 0.50 & 0.57 & 0.64 & 0.53 \\
$\mathrm{Al}_{2} \mathrm{O}_{3}$ & 12.02 & 13.48 & 11.97 & 11.97 & 14.36 \\
$\mathrm{Cr}_{2} \mathrm{O}_{3}$ & 0.00 & 0.00 & 0.01 & 0.01 & 0.00 \\
$\mathrm{Fe}_{2} \mathrm{O}_{3}$ & 0.28 & 0.24 & 0.39 & 0.29 & 0.62 \\
$\mathrm{MnO}$ & 0.68 & 0.50 & 0.94 & 0.56 & 0.23 \\
$\mathrm{CaO}$ & 45.29 & 44.15 & 43.01 & 42.29 & 38.34 \\
$\mathrm{MgO}$ & 4.09 & 5.61 & 6.41 & 8.12 & 9.76 \\
$\mathrm{Na} 2 \mathrm{O}$ & 0.08 & 0.12 & 0.16 & 0.20 & 0.23 \\
$\mathrm{~K}_{2} \mathrm{O}$ & 0.21 & 0.36 & 0.48 & 0.41 & 0.37 \\
$\mathrm{SO}_{3}$ & 1.17 & 1.38 & 1.83 & 1.14 & 1.13 \\
$\mathrm{P}_{2} \mathrm{O}_{5}$ & 0.00 & 0.00 & 0.00 & 0.00 & 0.00 \\
\hline
\end{tabular}

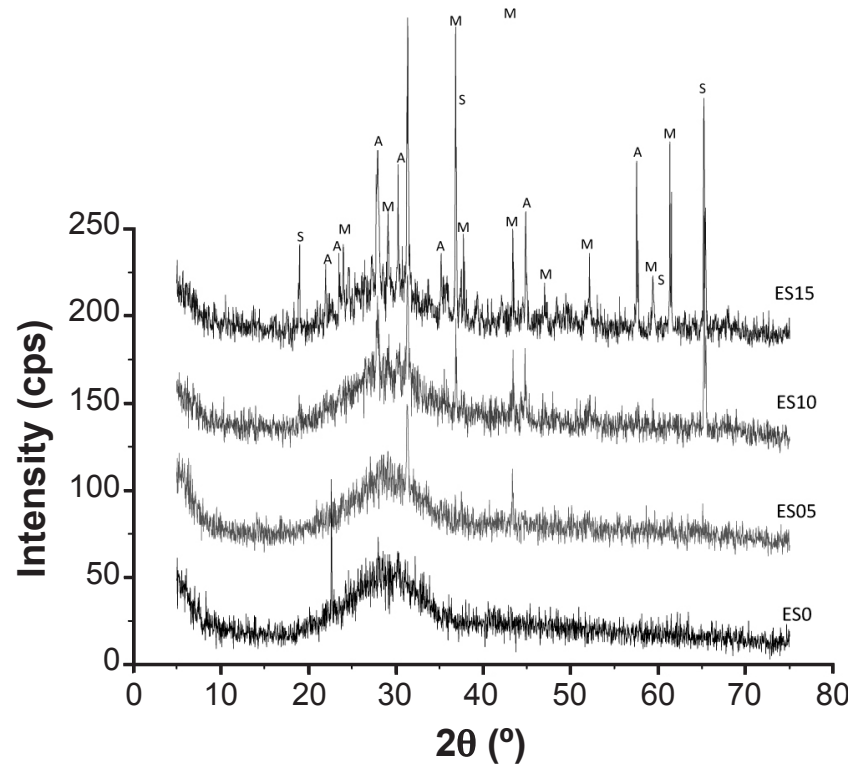

Figure 1: X-ray diffraction profiles of the synthetic slags: $\mathrm{M}=$ melilite $\left(\mathrm{Ca}_{8} \mathrm{Al}_{6} \mathrm{MgSi}_{5} \mathrm{O}_{28}\right), \mathrm{S}=\operatorname{spinel}\left(\mathrm{MgAl}_{2} \mathrm{O}_{4}\right), \mathrm{A}=$ anorthite $\left(\mathrm{CaAl}_{2} \mathrm{Si}_{2} \mathrm{O}_{8}\right)$.]

[Figura 1: Resultados da difração de raios $X$ das escórias sintéticas: $\mathrm{M}=$ melilita $\left(\mathrm{Ca}_{8} \mathrm{Al}_{6} \mathrm{MgSi}_{5} \mathrm{O}_{28}\right), \mathrm{S}=$ espinélio $\left(\mathrm{MgAl}_{2} \mathrm{O}_{4}\right)$, $A=\operatorname{anortita}\left(\mathrm{CaAl}_{2} \mathrm{Si}_{2} \mathrm{O}_{8}\right)$.]

industrial slags is presented in Table IV. The industrial slags evaluated were amorphous (X-ray diffraction results not shown here) due to the high cooling rate that these materials were submitted in the industrial process. Synthetic slags (Fig. 1), on the other hand, showed the following trend: the higher the $\mathrm{MgO}$ content, the higher the crystalline phase formation.

\section{EXPERIMENTAL PROCEDURES}

Contact angles of nine slags (synthetic and industrial) were measured using the sessile drop technique. Cylindrical 
pellets of $3 \mathrm{~mm}$ diameter and $5 \mathrm{~mm}$ high were pressed using the slag powders. For each test, the slag pellet was placed at the top center of the refractory substrate (10SBC castable or matrix). In order to produce these substrates, refractory sample bars $\left(150 \times 25 \times 25 \mathrm{~mm}^{3}\right)$ were previously fired under a reducing atmosphere at $1500{ }^{\circ} \mathrm{C}$ for $5 \mathrm{~h}$ and cut with a diamond saw into $25 \times 25 \times 10 \mathrm{~mm}^{3}$ plates. The surface of the substrates were ground and, in some cases, also polished.

The melting temperature of the slags was evaluated according to DIN 51730 standard [14]. The set (slag pellet and 10SBC substrate) was placed into a graphite resistance furnace (ASTRO, Fig. 2) and heated at $10{ }^{\circ} \mathrm{C} \cdot \mathrm{min}^{-1}$, under $0.1 \mathrm{MPa}$ argon atmosphere (99.999\% purity), up to the slag melting temperature. The shape profile of the sample (substrate + slag pellet) was recorded for later analyses. According to the DIN 51730 standard used in this study, the softening temperature is associated with the initial deformation of the slag pellet cylinder whereas, the melting temperature is determined when the pellet attained a half sphere shape.

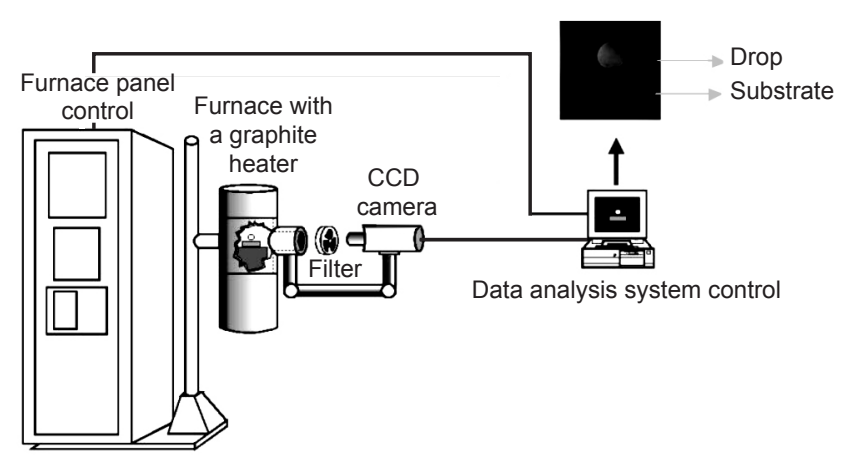

Figure 2: Sketch of the wettability testing system.

[Figura 2: Esquema ilustrativo do sistema usado nos testes de molhabilidade.]

Based on the slag melting temperatures, the temperature and time for the wetting experiments were chosen. The behavior of the slags on the 10SBC substrate was observed using an imaging capture system with a CCD video camera (JVC TK-C1480U, Thailand), a Matrox Meteor-II board (Matrox Electronic Systems Ltd., Canada) and an objective glass $4 / 50 \mathrm{~mm}$. At some time intervals, pictures of the drop shape evolution as a function of temperature and time were recorded. Pictures were also taken when visible changes in the liquid spreading on castable substrates could be noticed. The contact angle was measured for each picture using a QWin Leica software (Leica, Germany).

The aggregates with a particle size of $<4.75 \mathrm{~mm}$ can influence directly the liquid spreading on refractory castables. Thus, two sorts of substrates were used in the wetting experiments: a- 10SBC matrix substrates (particle size $<75 \mu \mathrm{m}$ - Table II) where the aggregates effect were not considered in the wetting behavior. For this experiment, the slag pellet and the substrate sizes were the same as stated above; b- $10 \mathrm{SBC}$ castable substrates $\left(25 \times 25 \times 10 \mathrm{~mm}^{3}\right)$ were used for the initial tests. Additionally, larger substrates (40 $\mathrm{mm}$ diameter and $10 \mathrm{~mm}$ high) and slag pellets $(8 \mathrm{~mm}$ diameter and $8 \mathrm{~mm}$ high) were also used for tests involving castable samples. The use of larger samples might provide a better description of the slag - refractory interaction behavior.

\section{RESULTS AND DISCUSSION}

\section{Melting temperatures}

Initially the melting temperatures of the synthetic and industrial slags on 10SBC matrix substrates were determined according to the DIN 51730 standard, by using three samples for each slag. The results are shown in Table V.

Table V - Melting temperature obtained in the wetting experiments and using the phase diagrams.

[Tabela $V$ - Temperatura de fusão obtida nos experimentos de molhabilidade e no diagrama de fases.]

\begin{tabular}{ccc}
\hline & \multicolumn{2}{c}{ Melting temperature $\left({ }^{\circ} \mathrm{C}\right)$} \\
\hline $\begin{array}{c}\text { Synthetic and } \\
\text { Industrial Slags }\end{array}$ & $\begin{array}{c}\text { Experimental } \\
\text { value }\end{array}$ & $\begin{array}{c}\text { Phase } \\
\text { Diagram }\end{array}$ \\
ES0 & $1330 \pm 5$ & 1328 \\
ES05 & $1280 \pm 10$ & $<1300$ \\
ES10 & $1270 \pm 11$ & $<1300$ \\
ES15 & $1275 \pm 11$ & $\approx 1400$ \\
Belgo & $1295 \pm 3$ & $1300<\mathrm{T}_{\mathrm{m}}<1400$ \\
Açominas & $1315 \pm 10$ & $>1400$ \\
Usiminas & $1320 \pm 10$ & $1300<\mathrm{T}_{\mathrm{m}}<1400$ \\
CST & $1360 \pm 9$ & $1300<\mathrm{T}_{\mathrm{m}}<1400$ \\
Siderar & $1330 \pm 6$ & $1300<\mathrm{T}_{\mathrm{m}}<1400$ \\
\hline
\end{tabular}

A comparison has been made between the synthetic slag results obtained and the $\mathrm{CaO}-\mathrm{Al}_{2} \mathrm{O}_{3}-\mathrm{SiO}_{2}$ and $\mathrm{CaO}-\mathrm{SiO}_{2}-$ $\mathrm{MgO}-15 \% \mathrm{Al}_{2} \mathrm{O}_{3}$ phase diagrams [15]. The use of this latter quaternary diagram was due to its similar $\mathrm{Al}_{2} \mathrm{O}_{3}$ content with the ES0, ES10 and ES15 synthetic slags. For the same reason, industrial slag melting temperatures were compared to the $\mathrm{CaO}-\mathrm{SiO}_{2}-\mathrm{MgO}-10 \% \mathrm{Al}_{2} \mathrm{O}_{3}$ and $\mathrm{CaO}-\mathrm{SiO}_{2}-\mathrm{MgO}-$ $15 \% \mathrm{Al}_{2} \mathrm{O}_{3}$ phase diagrams (Table IV).

ESO slag has a melting temperature value close to that shown in the phase diagram. For the other synthetic slags only a qualitative comparison was made due to the differences between their alumina content. As the $\mathrm{CaO}-\mathrm{MgO}$ $\mathrm{SiO}_{2}-15 \% \mathrm{Al}_{2} \mathrm{O}_{3}$ phase diagram was used and the synthetic slags presented $13 \% \mathrm{Al}_{2} \mathrm{O}_{3}$, some differences between the measured and phase diagram melting temperatures results are expected. Thus ES05, ES10, ES15 melting temperatures obtained by the phase diagram can not be considered accurate. This is a further advantage of measuring the melting point using the technique pointed out in this paper.

CST, Siderar and Usiminas melting temperatures are in agreement with the phase diagrams, but Açominas' and 
Belgo's slags presented lower values than expected. Once more, it was not possible to rely on the temperatures obtained by the phase diagram due to the different alumina content in the industrial slags. Additionally, other compounds in the slags might be changing the temperature and the DIN 51730 standard does not describe if the melting point measured corresponds to the slag or to the slag + substrate assembling.

With the purpose of correlating the slag melting temperatures and their basicity index, the following equation was used to calculate the values [15]:

$$
\text { Basicity index }=\frac{\% \mathrm{CaO}+0.5 \% \mathrm{MgO}}{\% \mathrm{SiO}_{2}+0.33 \% \mathrm{Al}_{2} \mathrm{O}_{3}}
$$

It was observed that in general the higher the basicity index the lower the melting temperature, except for the Siderar slag, which presented a deviation regarding this trend (Fig. 3). Besides that, synthetic and industrial slags showed similar values (around 0.8) for the $\mathrm{SiO}_{2} / \mathrm{CaO}$ ratio, except Siderar slag which was 0.9. Thus, Siderar slag behavior should be related not only to its $\mathrm{MgO}$ content, but also its higher $\mathrm{SiO}_{2} / \mathrm{CaO}$ ratio and distinct chemical composition

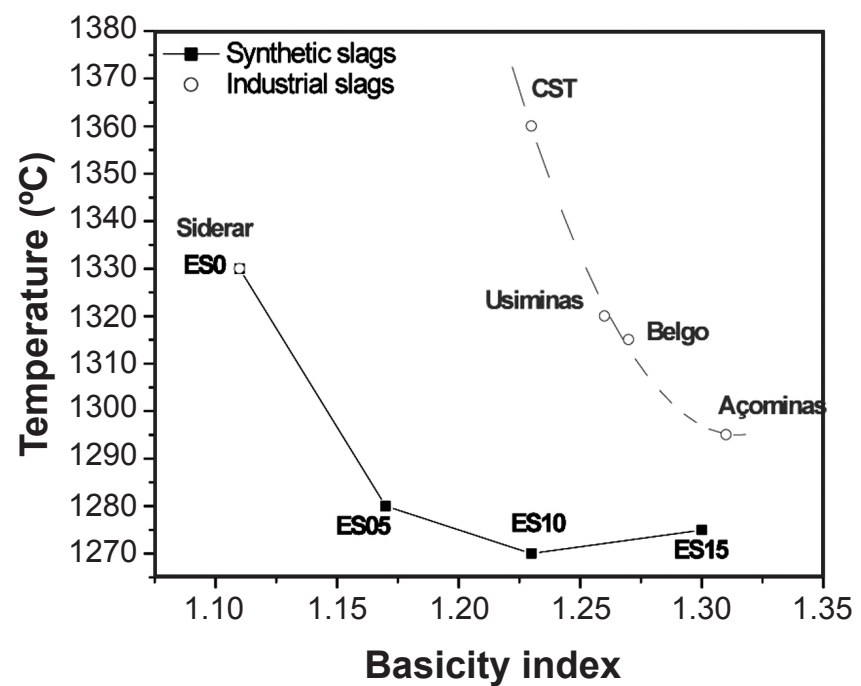

Figure 3: Comparison between basicity index and melting temperature.

[Figura 3: Comparação entre índice de basicidade e temperatura de fusão.]

Additionally, synthetic slags containing higher $\mathrm{MgO}$ content and consequently higher crystalline phase formation (Fig. 1), showed lower melting temperature, as presented in Fig. 3. The addition of $\mathrm{MgO}$ to the synthetic slags affects directly their melting points and allows the formation of crystalline phases.

By the results attained, the wetting experiments seem to be a good alternative to measure the melting temperatures of slags, because these values are difficult to determine by the phase diagrams due to the high oxide variety in the industrial slag compositions (specially Siderar one) and the slag - substrate interaction.

\section{Wettability}

For heterogeneous and rough solid surfaces, the advancing $\left(\theta_{\mathrm{a}}\right)$ and the receding $\left(\theta_{\mathrm{r}}\right)$ contact angles, which correspond to the largest and the smallest one, respectively, can be evaluated. The difference between the advancing and the receiving contact angle is the so-called contact angle hysteresis $[6,11,16]$. Over the past few decades, many researchers have studied the variation of apparent contact angle on rough substrates $[5,6,11,16-18]$.

The surface roughness affects wetting due to two different effects: firstly because the real surface area is higher and secondly due to the pinning of the triple line (solid-liquidvapor interface) by the sharp edges [6]. Thus, the effect of the refractory castable substrate surface finishing (ground or polished) on wetting and spreading of slags were evaluated. 10SBC matrix substrates were prepared in two different ways: with ground surfaces (grinding wheel greet $=600$ $\mu \mathrm{m}$ ) or polished (up to $0.25 \mu \mathrm{m}$ diamond suspension). For these wettability experiments two substrates (ground and polished) and two synthetic slags (ES0 and ES15) were used. The collected results are shown in Fig. 4.

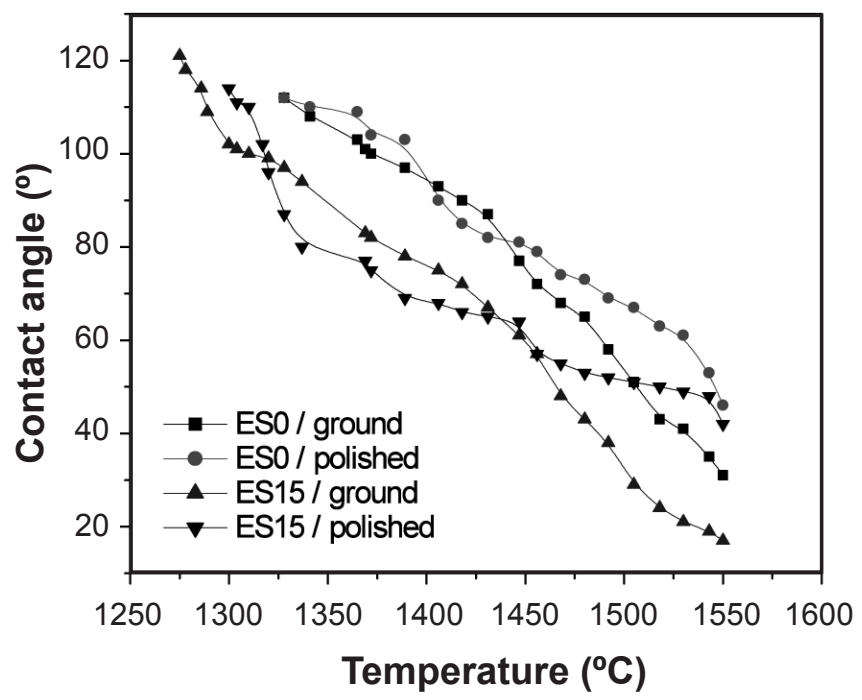

Figure 4: Contact angle versus temperature on ground and polished 10SBC matrix substrates.

[Figura 4: Angulo de contato versus temperatura em substratos retificados e polidos da matriz do concreto 10SBC.]

Besides the fact that the roughness of the substrate surface can change the wettability behavior, small differences between the ground and polished substrate, were observed. This behavior can be attributed to the grinding wheel greet used for the surface preparation of the samples and to the small slag drop size. Additionally to the roughness effect in the wetting behavior, previous studies have already pointed out the effect of the liquid drop size $[19,20]$. They showed that for a small drop, the properties and roughness of the solid plate are negligible. Thus, in order to visualize and better understand the influence of the roughness and the drop size on refractory wettability, larger castable substrates and 


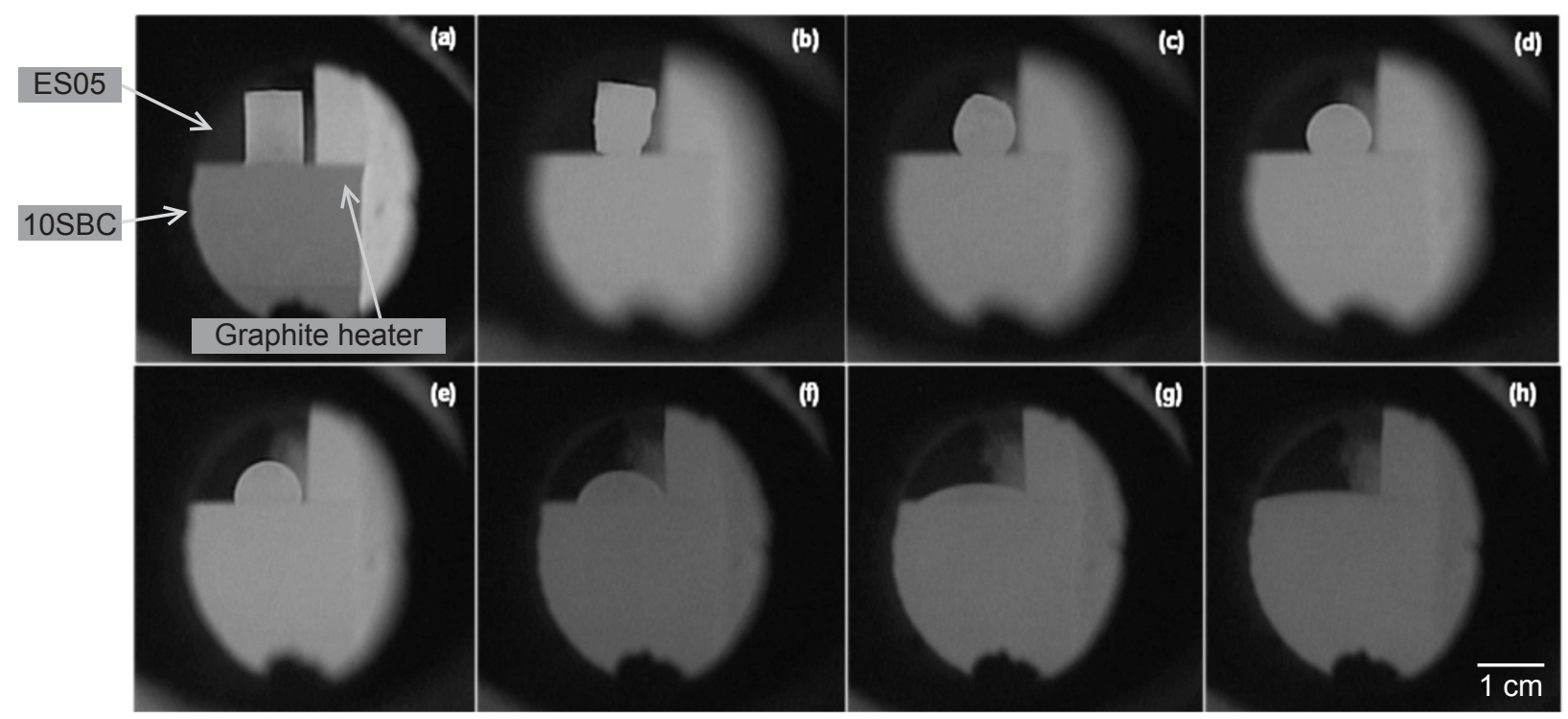

Figure 5: Wettability evolution of ES05 slag on 10SBC matrix substrate: (a) $930{ }^{\circ} \mathrm{C}$, (b) $1255^{\circ} \mathrm{C}$, (c) $1275^{\circ} \mathrm{C}$, (d) $1337{ }^{\circ} \mathrm{C}$, (e) $1431^{\circ} \mathrm{C}$, (f) $1480{ }^{\circ} \mathrm{C}$, (g) $1550^{\circ} \mathrm{C}$ and (h) $1550{ }^{\circ} \mathrm{C}$ after $10 \mathrm{~min}$ at this temperature.

[Figura 5: Evolução da molhabilidade da escória ES05 no substrato da matriz 10SBC: (a) $930{ }^{\circ} \mathrm{C}$, (b) $1255^{\circ} \mathrm{C}$, (c) $1275{ }^{\circ} \mathrm{C}$, (d) $1337^{\circ} \mathrm{C},(e) 1431{ }^{\circ} \mathrm{C},(\mathrm{f}) 1480^{\circ} \mathrm{C},(\mathrm{g}) 1550^{\circ} \mathrm{C}$ e (h) $1550^{\circ} \mathrm{C}$ depois de 10 min nesta temperatura.]

slag pellet samples were prepared for further evaluations. According to the results stated above, only ground substrates were chosen to be used in these experiments.

The following experiments evaluated the wetting behavior of synthetic and industrial slags on ground 10SBC matrix and castable substrates. Cylindrical slag pellets, $3 \mathrm{~mm}$ diameter and $5 \mathrm{~mm}$ high, and $25 \times 25 \times 10 \mathrm{~mm}^{3}$ substrates were used. The maximum temperature tested was $1550{ }^{\circ} \mathrm{C}$, due to the operational conditions that the blast furnace main runner is usually submitted. The dwell time at this temperature was about $10 \mathrm{~min}$, due to the large spreading attained and no expressive changes after this period. Some of the images collected along the wetting test are shown in Fig. 5.

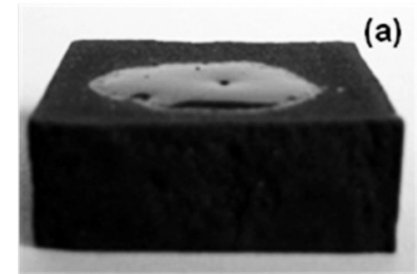

(a)
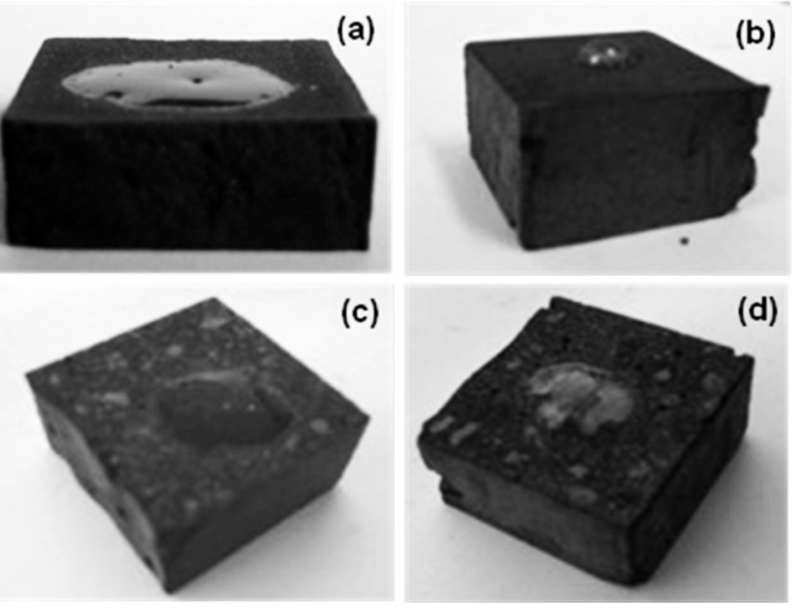

Figure 6: Samples after testing: (a) ES05 and (b) Usiminas' slag on matrix substrate; (c) ES05 and (d) Usiminas' slag on castable substrate.

[Figura 6: Amostras após teste: escórias (a) ES05 e (b) Usiminas sobre matriz; escórias (c) ESO5 e (d) Usiminas sobre concreto.]
Besides the synthetic slag ES05, experiments were also carried out with Usiminas' blast furnace slag using matrix and castable substrates. Photographs of the samples after the wettability experiments are presented in Fig. 6 and the contact angle attained as a function of the temperature, in Fig. 7. Although, ES05 and Usiminas' slags have similar values of $\mathrm{SiO}_{2} / \mathrm{CaO}$ ratio and alumina content, the differences in their chemical compositions (such as the presence of $\mathrm{MnO}$, $\mathrm{TiO}_{2}, \mathrm{SO}_{3}, \mathrm{~K}_{2} \mathrm{O}$, etc, in the Usiminas' material) influences the liquid spreading on the evaluated solid substrates.

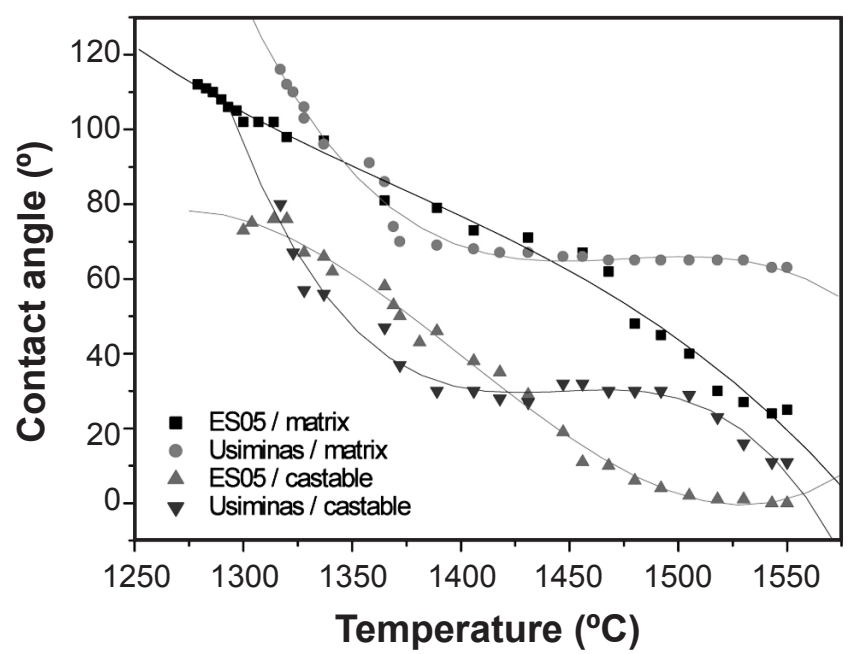

Figure 7: Contact angle behavior as a function of temperature on ground 10SBC substrates.

[Figura 7: Comportamento do ângulo de contato em função da temperatura nos substratos retificados do concreto 10SBC.]

For castable substrates, the contact angle decrease was faster when compared with the experiments performed on 

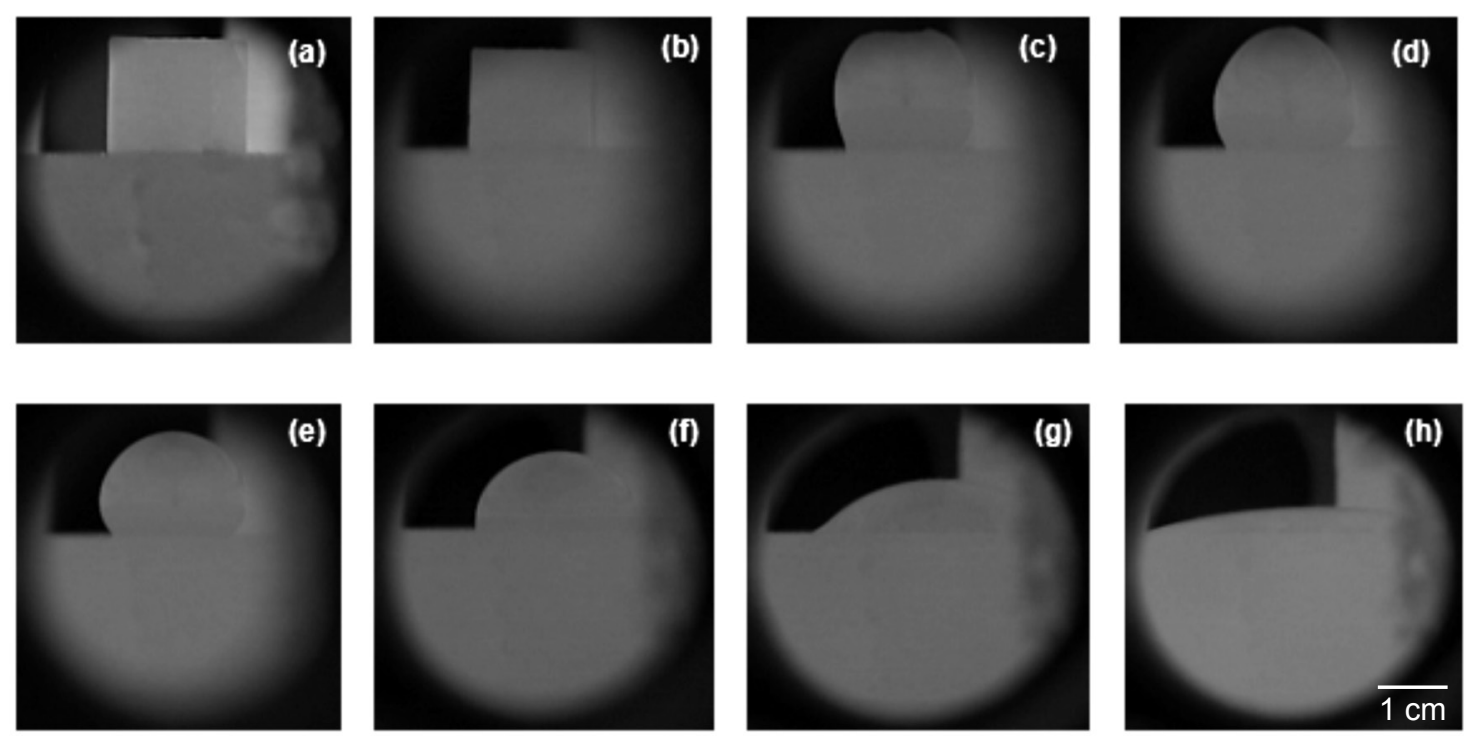

Figure 8: Wettability evolution of ES0 slag on ground $10 \mathrm{SBC}$ castable substrate: (a) $820^{\circ} \mathrm{C}$, (b) $1194{ }^{\circ} \mathrm{C}$, (c) $1225^{\circ} \mathrm{C}$, (d) $1228^{\circ} \mathrm{C}$, (e) $1230^{\circ} \mathrm{C}$, (f) $1389^{\circ} \mathrm{C}$, (g) $1468^{\circ} \mathrm{C}$ and (h) $1550{ }^{\circ} \mathrm{C}$.

[Figura 8: Evolução da molhabilidade da escória ESO no substrato retificado do concreto 10SBC: (a) $820{ }^{\circ} \mathrm{C}$, (b) $1194{ }^{\circ} \mathrm{C}$, (c) $1225^{\circ} \mathrm{C}$, (d) $1228^{\circ} \mathrm{C}$, (e) $1230^{\circ} \mathrm{C}$, (f) $1389^{\circ} \mathrm{C}$, (g) $1468{ }^{\circ} \mathrm{C}$ e (h) $1550{ }^{\circ} \mathrm{C}$.]
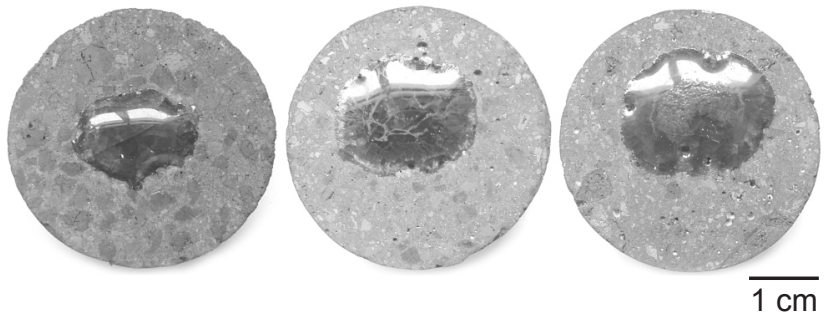

Figure 9: Samples showing the different liquid spreading on 10 SBC castables.

[Figura 9: Amostras com diferentes espalhamentos do liquido no concreto $10 \mathrm{SBC}$.]

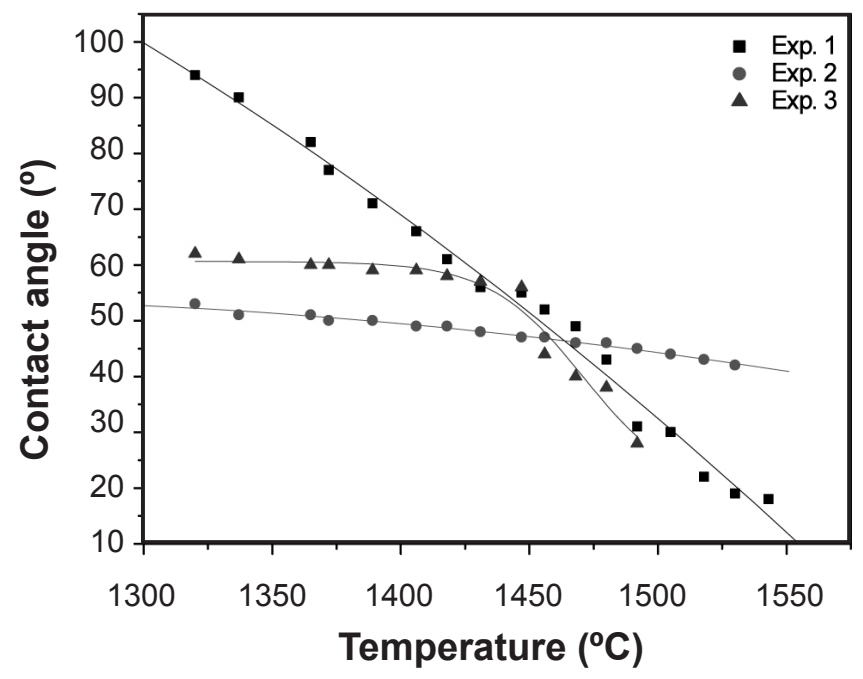

Figure 10: Contact angle versus temperature for ES0 slag on ground 10SBC castable substrate for 3 different experiments.

[Figura 10: Ângulo de contato versus temperatura da escória ESO no substrato retificado do concreto $10 S B C$ em 3 experimentos diferentes.] the matrix one. This behavior is attributed to the differences of the carbon content of the samples, as can be seen in Table II. The presence of $21 \mathrm{wt} \%$ of carbon in the matrix composition can explain the decrease of the slag wetting and its spreading on the substrate. Additionally, it was chosen to study the liquid-matrix interaction because the matrix has a higher porosity and a main role in the corrosion process of refractory castables. The matrix can be subjected to direct dissolution at refractory/slag interfaces by: (a) chemical reaction (or solution) at the interface, or (b) transport (or diffusion) of reacting species through the liquid [4]. Due to these particularities, it is expected that the corrosion will be more severe in the castable matrix.

Moreover, the aggregates and the castable chemical heterogeneous surface can also influence the slag spreading. Polycrystalline phases strongly modify the wetting of these substrates, especially at high temperatures, resulting in a large spreading in the $\theta$ values. Additionally, solids obtained by sintering, as most of the ceramics, have some microporosity which can also pin the triple line $[2,6]$. Thus, the reliability of the results attained in the matrix and castable was evaluated, due to the large number of parameters that can influence and change the refractory castable wettability. Moreover, the drop size effect on the contact angle was analyzed, because 10SBC castable composition contains aggregates with a particle size smaller than $4.75 \mathrm{~mm}$ and if the drop is too small, the contact angle might not represent the whole liquid-solid interaction.

As stated in the experimental procedures, some wetting experiments with castable substrates were performed using samples with the following dimensions: $40 \mathrm{~mm}$ diameter and $10 \mathrm{~mm}$ high castable substrates and $8 \mathrm{~mm}$ diameter 
and $8 \mathrm{~mm}$ high slag pellets. The use of larger samples can provide results that better represent the interaction slagcastable. For the matrix evaluation, smaller substrates $\left(25 \times 25 \times 10 \mathrm{~mm}^{3}\right)$ and $3 \mathrm{~mm}$ diameter and $5 \mathrm{~mm}$ high slag pellets, were still used. For each slag-substrate set, three experiments were performed.

Larger cylindrical slag samples promoted the formation of a greater amount of liquid and spreading on the castable substrates (Fig. 8 and 9). Due to the large liquid spreading and equipment restriction, the contact angle measurement was evaluated up to $1530{ }^{\circ} \mathrm{C}$. Preferential spreading was observed when the liquid was in contact with some $\mathrm{Al}_{2} \mathrm{O}_{3}$ aggregates. Liquid slags can be expected to easily wet oxide components. However, when the liquid was in contact with $\mathrm{SiC}$ aggregates, the spreading was inhibited. The differences in the interfacial surface tensions of the solid-liquid interfaces and the presence of polycrystalline phases are the main reasons for the contact angle changes on the castable heterogeneous surface [8]. The presence of $\mathrm{Al}_{2} \mathrm{O}_{3}$ and $\mathrm{SiC}$ aggregates induced an unsymmetrical drop spreading on the castable surface. All these quoted aspects contributed to reveal a poor reliability of the slag wetting behavior on the castable samples (Fig. 10). Besides that, some pores are found in the castable structure, as observed in Fig. 9. The variation of the contact angles with temperature might also be induced by the slag infiltration into the porosity of the castable samples.

Additionally, increasing the drop size minimizes the effect of the rough substrate surface and small contact angles can be attained $\left(\theta>55^{\circ}\right)$. However, because the gravity force can improve the liquid spreading on a solid, there is a limit in the drop size increase, without a direct influence in the contact angle. When only the contact angle is needed, small droplets weighing typically $10^{-2}-10^{-1} \mathrm{~g}$ (e.g., cylindrical

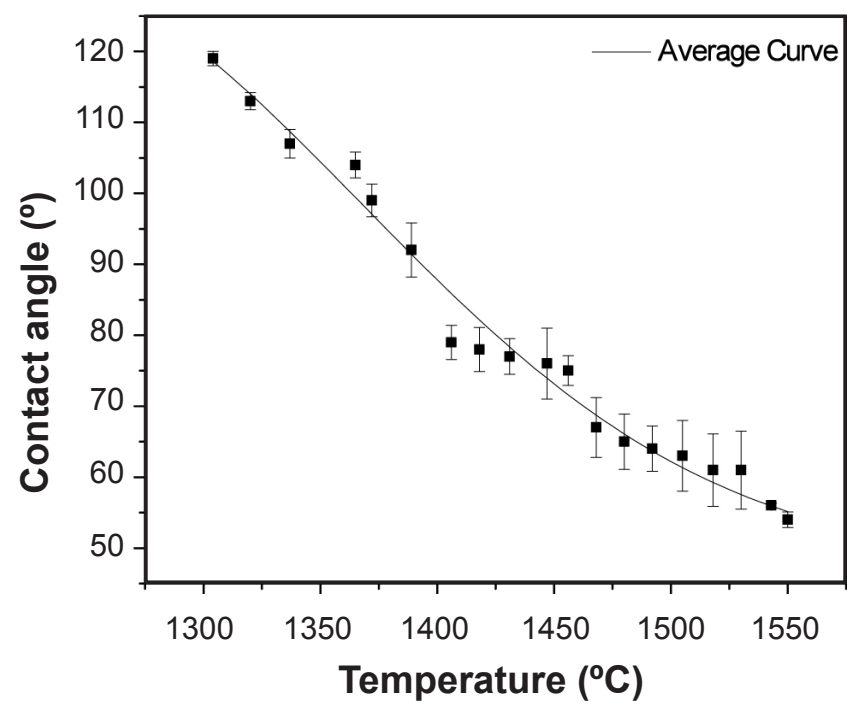

Figure 11: Contact angle versus temperature for ES0 slag on ground 10SBC matrix with the standard deviation considering 3 samples. [Figura 11: Angulo de contato versus temperatura da escória ESO sobre a matriz retificada do concreto $10 S B C$ com seu desvio padrão - considerando 3 experimentos.]
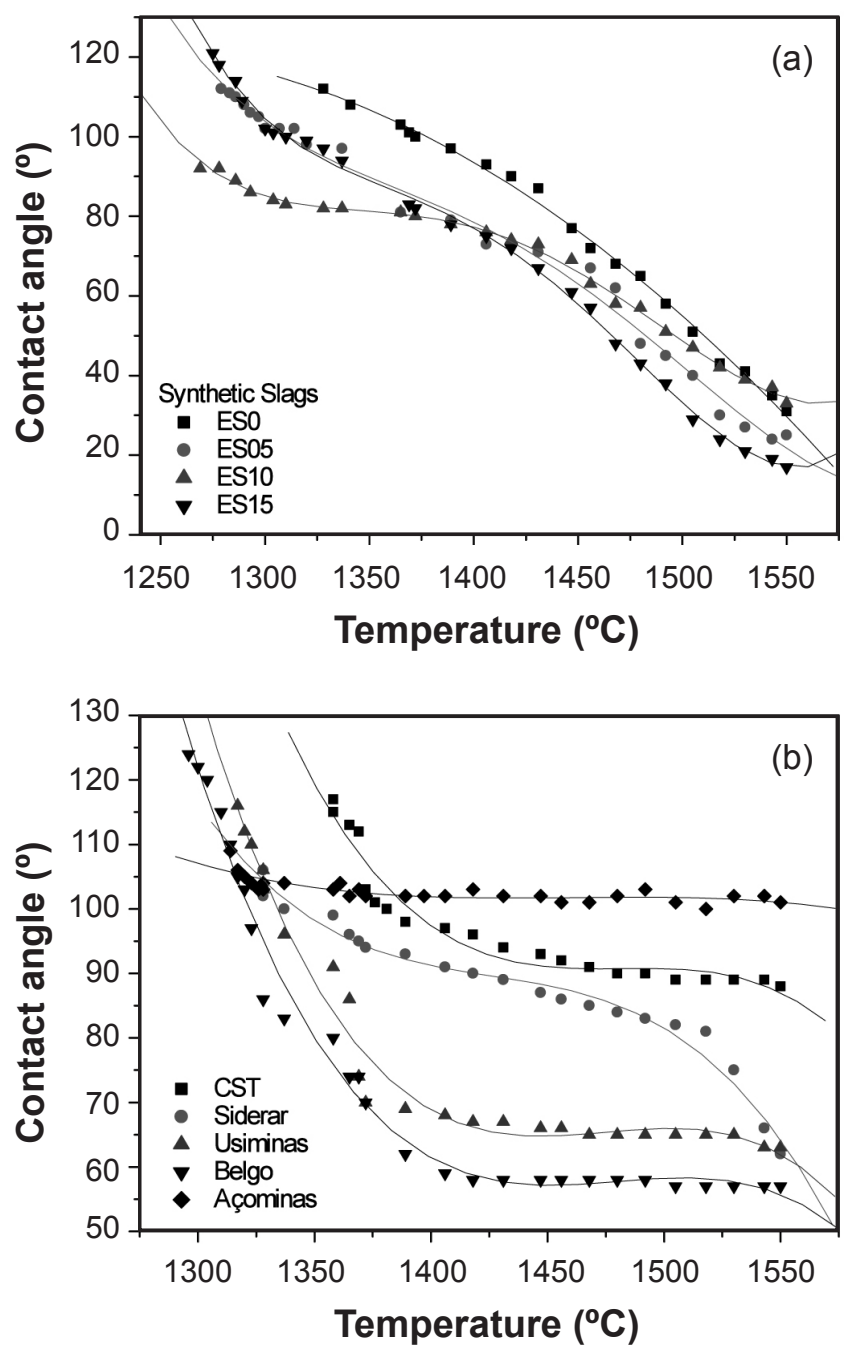

Figure 12: Contact angle behavior as a function of temperature for: (a) synthetic and (b) industrial slags on 10SBC matrix substrate.

[Figura 12: Comportamento do ângulo de contato em função da temperatura para: escórias (a) sintéticas e (b) industriais na matriz do 10SBC.]

pellets of $3 \mathrm{~mm}$ diameter and $5 \mathrm{~mm}$ high) are preferable as the deformation of the drop by gravity can be neglected in such conditions [6].

The contact angle values are quite reliable when the ground 10SBC matrix substrate was evaluated (see Fig. 11). The standard deviation considering the three tests performed on matrix substrates confirms the good reliability of the wetting behavior. As discussed before, the quality of the solid surface finishing and the small slag drop size might be responsible for the good results attained. Additionally, the gravity effect on the wetting behavior was neglected due to the use of small slag pellet sizes.

Experiments carried out with the other synthetic slags in castable substrates showed the same behavior as ESO slag. After the evaluation of the ground and polished castable and matrix samples, and two different sizes of substrates and slag drop, the best conditions attained for performing the wetting tests were chosen. The use of $25 \times 25 \times 10 \mathrm{~mm}^{3}$ matrix samples with a ground surface and $3 \mathrm{~mm}$ diameter and $5 \mathrm{~mm}$ 
high slag pellets seems to be the most appropriate set for the composition analyzed, concerning the reliability of the results. Thus, for further studies the use of matrix specimens can give us a better indicative of the wettability behavior.

In order to continue this study, different sorts of synthetic and industrial slags on matrix castable samples were tested. The results are shown in Fig. 12 where all slags presented good wetting $\left(\theta<90^{\circ}\right.$, except the Açominas and CST ones) and the contact angle decreases with increasing the temperature.

Industrial slags present high viscosities and therefore the liquid spreading on the matrix substrate is slower and, consequently, the contact angles values are higher. At high temperatures, there is a decrease of slag viscosity promoting a higher liquid spreading in a shorter time. The molten slag viscosity has significant effects on slag spreading, penetration and dissolution of refractories. A more fluid slag will better penetrate and is more likely to dissolve the solid refractory [4]. Comparing the basicity index values (Fig. 3 ) and the contact angle behavior, it was observed that in general the lower the contact angle, the higher the basicity index (except Açominas and CST slag which presented $\theta>$ $\left.90^{\circ}\right)$.

At $1550{ }^{\circ} \mathrm{C}$, the slag + substrate set was observed for the first $10 \mathrm{~min}$, in order to evaluate the changes in the contact angle as a function of time (Fig. 13). At $1550{ }^{\circ} \mathrm{C}$, synthetic slags showed bubbles just after few minutes at this temperature, inhibiting the measurement of the contact angle. This behavior might be related to the gas formation after the interaction slag-refractory. Some chemical reactions at this temperature range are [21]:

$$
\begin{gathered}
\mathrm{Al}_{6} \mathrm{Si}_{2} \mathrm{O}_{13(\mathrm{~S})}+6 \mathrm{C}_{(\mathrm{S})} \leftrightarrow 2 \mathrm{SiC}_{(\mathrm{S})}+3 \mathrm{Al}_{2} \mathrm{O}_{3(\mathrm{~S})+} 4 \mathrm{CO}_{(\mathrm{g})} \\
\mathrm{MgO}_{(\mathrm{l}, \mathrm{S})}+\mathrm{C}_{(\mathrm{S})} \leftrightarrow \mathrm{Mg}_{(\mathrm{g})}+\mathrm{CO}_{(\mathrm{g})} \\
\mathrm{SiC}_{(\mathrm{S})}+\mathrm{CO}_{(\mathrm{g})} \leftrightarrow \mathrm{SiO}_{(\mathrm{g})}+2 \mathrm{C}_{(\mathrm{g})}
\end{gathered}
$$

For the industrial slags, increasing the time at a certain temperature also increased the spreading of the liquid and, consequently, lower contact angles between slag-refractory were attained. Açominas and CST slags changed from non-wetting to wetting conditions $\left(\theta \geq 90^{\circ}\right)$ after a few minutes at $1550{ }^{\circ} \mathrm{C}$. No bubble formation was observed in the experiments with industrial slags, most likely due to its higher viscosity.

\section{CONCLUDING REMARKS}

After the evaluation of the wettability behavior of various slags on carbon refractory, it can be concluded that: -the wetting experiments seems to be a good alternative to measure the melting temperatures of slags, because based on the phase diagrams and basicity index, their values are
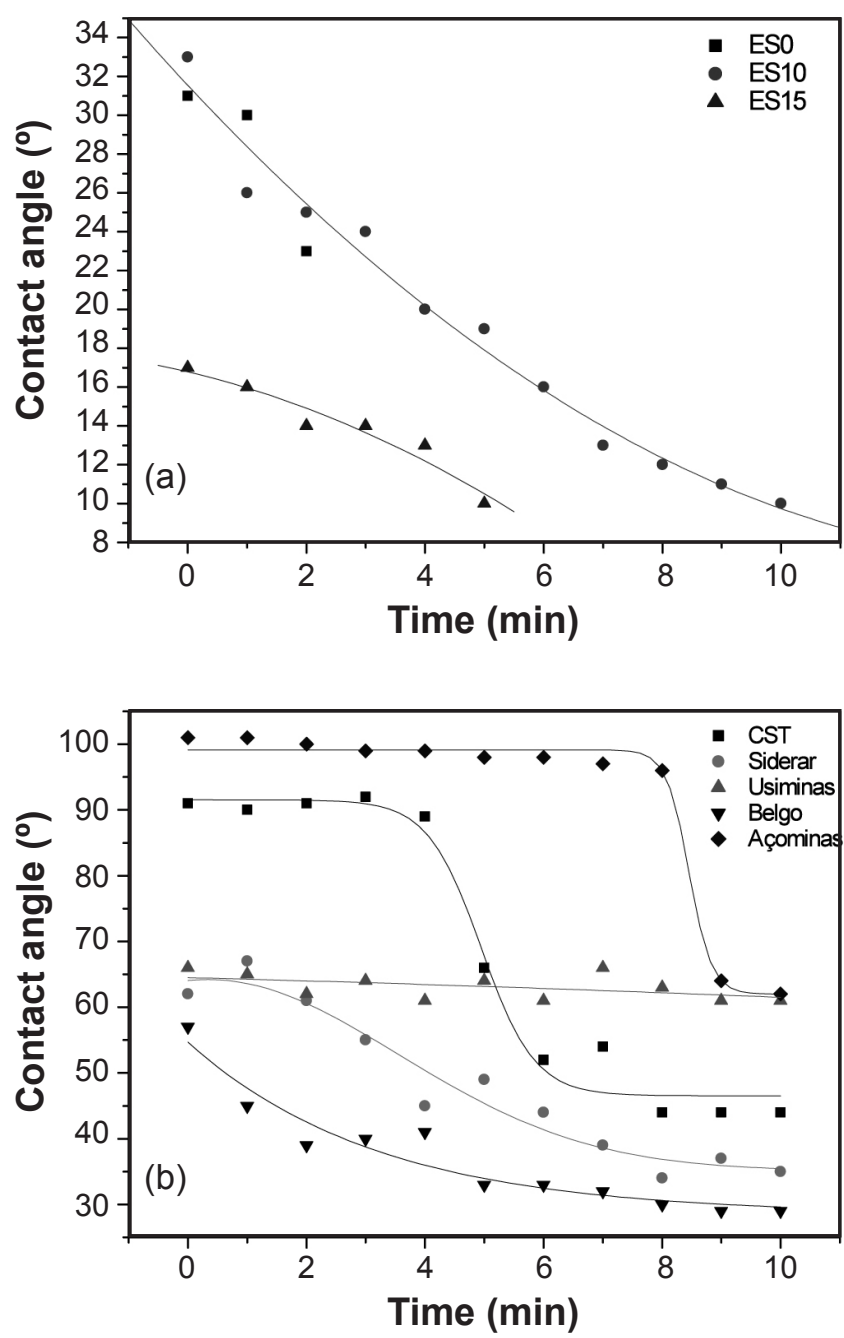

Figure 13: Contact angle behavior as a function of time for: (a) synthetic and (b) industrial slags on 10SBC matrix substrate.

[Figura 13: Comportamento do ângulo de contato em função do tempo para: escórias (a) sintéticas e (b) industriais na matriz do 10SBC.]

difficult to be correctly attained due to the high oxide variety in the industrial slag compositions and the slag - substrate interaction. - the use of a refractory matrix substrate seems to be the best alternative to study the wetting behavior of refractory castables, as the presence of aggregates and the phase complexity in these materials influence the reliability of the results attained. Besides that, it is known that the castable matrix is more prone to react with liquid slags at high temperature due to its high porosity and faster dissociation in the slag due to its finer grain size. Therefore, the liquidmatrix interaction has a particular role in the corrosion process of refractory castables. - small differences between the contact angle behavior on ground and polished matrix surfaces for synthetic slags were detected. This behavior can be attributed to the grinding wheel (smooth surface finishing $=600 \mu \mathrm{m}$ ) used in the surface preparation of the samples and to the small slags drop size. - the use of bigger drop size in the evaluation of slag - castable substrate wetting behavior resulted in poor reliability concerning the contact angle for 
the same slag - refractory set. These results indicated that the use of matrix substrate should be more appropriate for further investigations due to the main role of this phase in the corrosion process of refractory castables. - the chemical composition of the slags directly influences the liquid spreading on the refractory castable analyzed. Industrial slags containing various oxide components, showed high values of contact angles and lower liquid spreading when compared with synthetic slags. This difference can be associated to the interaction liquid-solid at the material interface. For further studies, the slag-refractory interface will be analyzed. - according to the present study, the best test conditions for the evaluation of the wetting behavior of refractory castables are: $25 \times 25 \times 10 \mathrm{~mm}^{3}$ matrix samples with a ground surface and $3 \mathrm{~mm}$ diameter and $5 \mathrm{~mm}$ high cylindrical slag pellets.

Wetting results should not necessarily follow the same trend of the dynamic corrosion tests, but can be closer to the static ones (no temperature gradient, rapid saturation of slag composition with reaction products and no slag relative motion). However, it should be pointed out that wettability behavior is an important tool to evaluate the thermodynamic aspects, the chemical interaction (interface and surface energies, the slag penetration) and the melting temperatures of the slags in contact with the refractory material.

\section{ACKNOWLEDGMENTS}

The authors are grateful to FAPESP for the financial support and to Magnesita S/A, Alcoa Alumínio S/A, Treibacher, Unimetal, Nacional de Grafite and Elkem Refractories, all from Brazil, for kindly supplying the raw materials.

\section{REFERENCES}

[1] F. H. Almusalami, R. C. Bradt, Proceedings UNITECR 2003 Congress, Osaka, Japan (2003) 21A-16.

[2] F. H. Almusalami, R. C. Bradt, Proc. Copper 2003 Cobre 2003, Santiago, Chile (2003) 473-483.
[3] N. Sobczak, M. Singh, R. Asthana, Current Opinion in Solid State and Materials Science 9 (2005) 241-253.

[4] W. E. Lee, S. Zhang, Int. Mater. Rev. 44 (1999) 77-104.

[5] K. N. Prabhu, P. Fernades, G. Humar, Mater. Design 30 (2009) 297-305.

[6] N. Eustathopoulos, N. Sobczak, A. Passerone, K. Nogi, J. Mater. Sci. 40 (2005) 2271-2280.

[7] D. N. Rao, Colloids and Surface A: Physicochem. Eng. Aspects 206 (2002) 203-216.

[8] N. Eustathopoulos, M. G. Nicholas, B. Drevet, Wettability at high temperatures, Pergamon Materials Series, Netherlands (1999) 20-40.

[9] N. Siddiqi, B. Bhoi, R. K. Paramguru, V. Sahajwalla, O. Ostrovski, Ironmaking Steelmaking 27 (2000) 367-372.

[10] N. Siddiqi, B. Bhoi, R. K. Paramguru, V. Sahajwalla, O. Ostrovski, Ironmaking Steelmaking 27 (2000) 437-441.

[11] C. G. Aneziris, M. Hampel, Int. J. Appl. Ceram. Technol. 5 (2008) 469-479.

[12] C. Chan, B. B. Argent, W. E. Lee, J. Am. Ceram. Soc. 81 (1998) 3177-88.

[13] V. G. Domiciano, J. R. Garcia, V. C. Pandolfelli, Am. Ceram. Soc. Bull. 84 (2005) 31-36.

[14] DIN 51730, Determination of fusibility of fuel ash, German Standard (1984).

[15] M. Allibert et al., Slag Atlas, Verlag Stahleisen GmbH, Dusseldorf, Germany (1995) 165.

[16] J. Long, M. N. Hyder, R. Y. M. Huang, P. Chen, Advances Colloid Interf. Sci. 118 (2005) 173-190.

[17] P. J. Ramón-Torregrosa, M. A. Rodríguez-Valverde, A. Amirfazli, M. A. Cabrerizo-Vílchez, Colloids Surfaces A: Physicochem. Eng. Aspects 323 (2008) 83-93.

[18] K. M. Hay, M. I. Dragila, J. Liburdy, J. Colloid Interf. Sci. 325 (2008) 472-477.

[19] E. Y. Arashiro, N. R. Demaquette, Mater. Res. 2 (1999) 23-32.

[20]A. Gajewski, Int. J. Heat Mass Transfer 51 (2008) 46284636.

[21] S. Zhang, W. E. Lee, J. Eur. Ceram. Soc. 21 (2001) 2393-2405.

(Rec. 10/04/2009, Rev. 17/08/2009, Ac. 04/09/2009) 